PNL-2924

UC-41

\title{
Sequim Marine Research Laboratory Routine Environmental Measurements During CY-1978
}

J. R. Houston

P. J. Blumer

March 1979

Prepared for the U.S. Department of Energy under Contract EY-76-C-06-1830

Pacific Northwest Laboratory Operated for the U.S. Department of Energy by Battelle Memorial Institute 
This report was prepared as an account of work sponsored by the United States Government. Neither the United States nor the Department of Energy, nor any of their employees, nor any of their contractors, subcontractors, or their employees, makes any warranty, express or implied, or assumes any legal liability or responsibility for the accuracy, compieteness or usefulness of any information, apparatus, product or process disclosed, or represents that its use would not infringe privately owned rights.

The views, opinions and conclusions contained in this report are those of the contractor and do not necessarily represent those of the United States Covernment or the United States Department of Energy.

\author{
PACIFIC NORTHWEST LABORATORY \\ operated by \\ BATTELLE \\ for the \\ UNITED STATES DEPARTMENT OF ENERGY \\ Unider Contract EY-76-C-06-1830
}

\author{
Printed in the United States of America \\ Available from \\ National Technical Information Service \\ United States Department of Commerce \\ 5285 Port Royal Road \\ Springfield, Virginia 22151
}

Price: Printed Copy 5

; Microfiche $\$ 3.00$

NTIS

-Pages Selling Price

001-025 $\quad \$ 4.00$

026-050 $\quad 54.50$

051-075 $\quad \$ 5.25$

076-100 $\quad \$ 6.00$

$107.125 \quad \$ 6.50$

$126-150 \quad \$ 7.25$

$151-175 \quad \$ 8.00$

$176-200 \quad \$ 9.00$

201-225 $\quad 59.25$

226-250 $\$ 9.50$

$251-275 \quad \$ 10.75$

$276-300 \quad \$ 11.00$ 
PNL-2924

UC-41

\title{
33679000533150
}

SEQUIM MARINE RESEARCH LABORATORY ROUTINE ENVIRONMENTAL MEASUREMENTS DURING CY-1978

\author{
J.R. Houston \\ P.J. Blumer
}

March 1979

Prepared for

The U.S. Department of Energy

Under Contract EY-76-C-06-1830

Pacific Northwest Laboratory

Richland, Washington 99352 



\section{SUMMARY}

Environmental data collected during 1978 in the vicinity of the Marine Research Laboratory show continued compliance with a 17 applicable state and federal regulations and furthermore show no detectable change from conditions that existed in previous years. 
.

.

-.

- 


\section{CONTENTS}

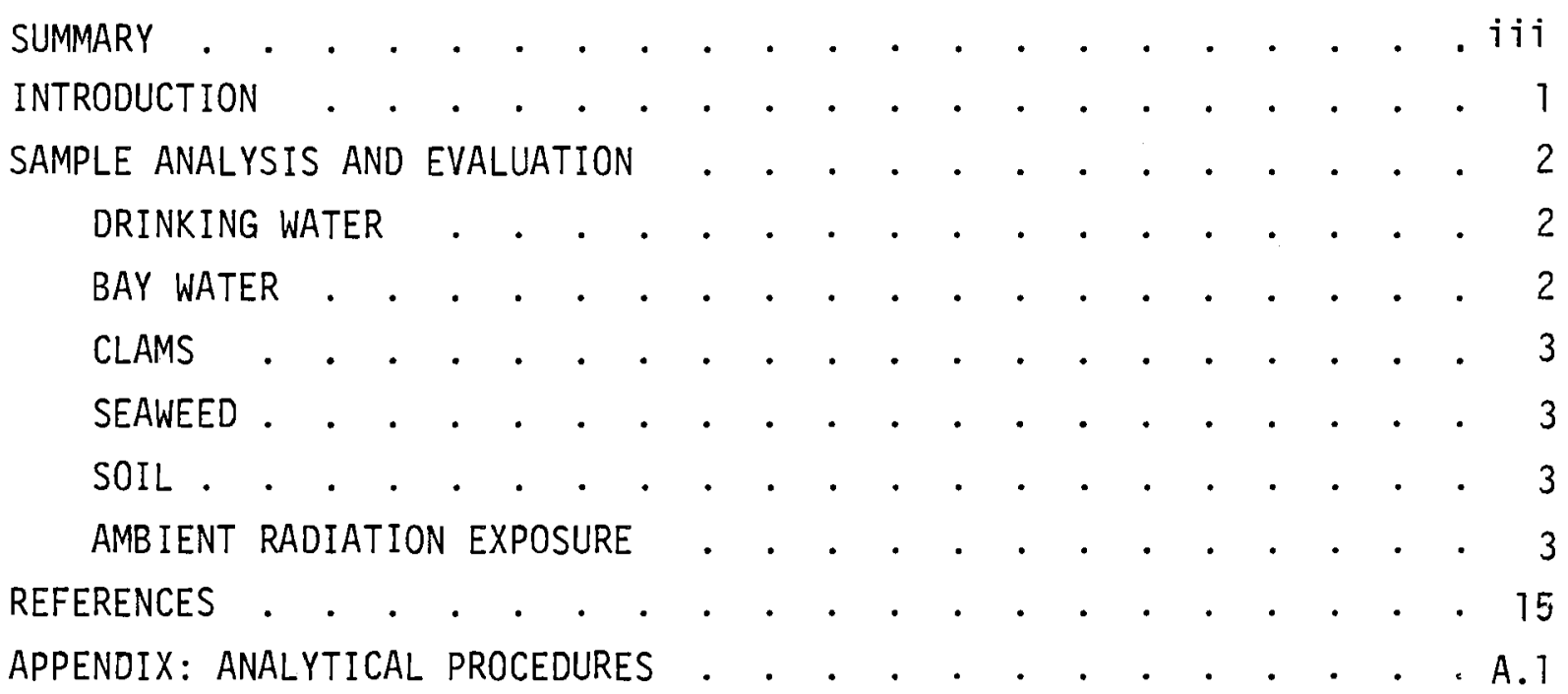




\section{TABLES}

1. MRL Environmental Sampling Schedule . . . . . . . . . 5

2. Concentrations of Radionuclides in Drinking-Water Samples from Sequim (Grab Samples) . . . . . . . . . . 6

3. Total Coliform Analyses of Sequim MRL Drinking Water . . . . 7

4. Concentrations of Radionuclides in Bay Water Samples from Sequim (Grab Samples) . . . . . . . . . . . . 8

5. Concentrations of $0 i 1$ and Copper in Bay Water Samples from Sequim (Grab Samples)

6. Concentrations of Radionuclides in Clams Collected at Sequim . . . . . . . . . . . . . . . . . . . 10

7. Concentrations of Radionuclides in Kelp and Eelgrass Samples from Sequim . . . . . . . . . . . . . . . 11

8. Concentration of Radionuclides in Sequim Soil Samples . . . . . . . . . . . . . . . . . . 12

9. External Radiation Dose Rates at MRL . . . . . . . . 14 


\section{INTRODUCTION}

A routine environmental surveillance program has been conducted at the Marine Research Laboratory (MRL) at Sequim, Washington, since 1976. The purpose of the program is to assess the impact of laboratory operations on the MRL environs. During the first two years of operation, sufficient data were collected to provide a base of information against which later measurements could be compared.

The program is designed primarily to determine the concentrations of radionuclides in selected biota in Sequim Bay. The biota sampled are selected because of their presence near the laboratory and their capacity to concentrate trace elements. Several other samples are obtained to determine the radionuclide concentrations in Sequim Bay, the surface deposition of fallout radionuclides, and the concentration of radionuclides in laboratory drinking water. Ambient radiation exposure rates at several locations around the laboratory are also measured. Methods used to analyze the samples are summarized in the Appendix.

A11 data collected each year are presented and evaluated in a series of annual reports. $(1,2)$ Included in this report are data collected during calendar year 1978 and analytical data available from previous years. Evaluation of the data is based on comparison with historical data and on regulatory requirements promulgated by the state of Washington or the U.S. Environmental Protection Agency. 
A number of environmental media from the MRL environs were sampled and analyzed during 1978. The collection and analysis schedule for these samples is shown in Table 1. Specific details on the analysis of each medium and its evaluation follow.

DRINKING WATER

Results of radiological analyses for gross beta and gross alpha activity, tritium, and gamma-emitting radionuclides in drinking-water samples are shown in Table 2. Concentrations that are less than the associated counting uncertainty are considered to be below detection capabilities. With the exception of an occasional result, all those listed in Table 2 are below detection capabilities. The two 1978 results that are above the detection limit are attributed to radionuclides from worldwide fallout. There is no indication that MRL activities have contributed to the observed concentrations.

Coliform analyses were performed quarterly by the 0lympic Health District in 1978. The results, presented in Table 3, continue to show that the drinking water is within state standards of less than 2 organisms per $100 \mathrm{ml}$ of water.

BAY WATER

Shown in Table 4 are the results of the radiochemical analyses of Sequim Bay water samples. With a few exceptions, the radionuclide concentrations are all below detection capabilities. The positive values are attributed to naturally occurring radionuclides and/or worldwide fallout. There is no indication that MRL operations have contributed to the observed concentrations.

Bay water samples were not analyzed for copper or oil and grease in 1978 due to an oversight. Data from previous years are shown in Table 5. 


\section{CLAMS}

Results for the three varieties of clam collected to date are shown in Table 6. In 1978, naturally occurring $40 \mathrm{~K}$ was detected in the clams as expected, in addition to plutonium from worldwide fallout. Concentrations of all other radionuclides were below the detection limit. None of the detectable radioactivity is attributable to MRL operations.

\section{SEAWEED}

The analytical results for kelp and eelgrass collected from Sequim Bay are shown in Table 7. Detectable radionuclides are either naturally occurring $(40 \mathrm{~K})$ or due to worldwide fallout $\left({ }^{0}{ }^{\circ} \mathrm{Sr}\right.$ and $\left.\mathrm{Pu}\right)$. Here again, none of the detectable radionuclides are attributable to MRL operations.

SOIL

The results of radiochemical analyses of soil samples collected to date from two locations in the immediate vicinity of MRL are shown in Table 8. Sampling locations are shown in Figure 1. The relatively low concentrations of naturally occurring ${ }^{40} \mathrm{~K},{ }^{22}{ }^{4} \mathrm{Ra}$, and ${ }^{226} \mathrm{Ra}$ are typical of many coastal areas. (3)

During 1978, small positive results were obtained from analyses for ${ }^{90} \mathrm{Sr},{ }^{137} \mathrm{Cs}$, and $239-240 \mathrm{Pu}$. All of this observed radioactivity is attributed to worldwide fallout. All values were within the expected range of soil activity for the MRL environs.

\section{AMBIENT RADIATION EXPOSURE}

External radiation levels measured at four locations at MRL are summarized in Table 9. These measurements were made using thermoluminescent dosimeters placed 1 meter above ground level. Each dosimeter consists of five chips of $\mathrm{CaF}_{2}: \mathrm{Mn}$ (Harshaw TLD-400) encased in an opaque capsule lined with 0.002 inches of lead and 0.01 inches of tantalum. (4) The dosimeters are exposed for periods of about one month at the locations shown in Figure 1 , then changed and read out. The exposure periods overlap a few days because 
of mail and processing delays. The annual external radiation dose of about 45 mrad found in 1978 is significantly lower than the dose observed in most inland areas but is typical of the dose in many coastal plain areas. (3) The relatively low ambient external dose rate is due to the relatively low concentrations of naturally occurring radionuclides at MRL. Results for 1978 are consistent both from month to month and from location to location and are essentially the same as those for previous years, indicating no contribution from MRL operations. 
TABLE 1. MRL Environmental Sampling Schedule

\begin{tabular}{|c|c|c|c|c|c|}
\hline \multirow[b]{2}{*}{ Sample Type } & \multirow[b]{2}{*}{$\begin{array}{l}\text { Number of } \\
\text { Locations }\end{array}$} & \multirow[b]{2}{*}{ Frequency } & \multirow[b]{2}{*}{$\begin{array}{l}\text { Quantity } \\
\text { Sampled }\end{array}$} & \multicolumn{2}{|c|}{ Analyses } \\
\hline & & & & Radiological & Other \\
\hline$T_{L D}(a)$ & 4 & Monthly & -- & External Radiation & \\
\hline Bay water & 1 & Semiannual ly & $4 \ell$ & $\begin{array}{l}\text { Gamma scan } \\
\text { Gross beta } \\
\text { Gross alpha } \\
\text { Tritium }\end{array}$ & $\begin{array}{l}\text { Heavy metals }(b) \\
0 i 1 \text { and grease }\end{array}$ \\
\hline $\begin{array}{l}\text { Drinking } \\
\text { Water }\end{array}$ & 1 & Semiannually & $1 \ell$ & $\begin{array}{l}\text { Gamma scan } \\
\text { Gross beta } \\
\text { Gross alpha } \\
\text { Tritium }\end{array}$ & Coliforms \\
\hline Kelp & 1 & Quarterly & $2 \mathrm{~kg}$ & $\begin{array}{l}\text { Gamma scan } \\
90 \mathrm{Sr} \\
\text { Total Pu }\end{array}$ & \\
\hline Eelgrass & 1 & Quarterly & $2 \mathrm{~kg}$ & $\begin{array}{l}\text { Gamma scan } \\
{ }^{90} \mathrm{Sr} \\
\text { Total } \mathrm{Pu}\end{array}$ & \\
\hline Clams & 1 & & $2 \mathrm{~kg}$ & $\begin{array}{l}\text { Gamma scan } \\
{ }^{90} \mathrm{Sr} \\
\text { Total } \mathrm{Pu}\end{array}$ & \\
\hline Soil & 2 & Annually & $2 \mathrm{~kg}$ & $\begin{array}{l}\text { Gamma scan } \\
90 \mathrm{Sr} \\
\text { Total } \mathrm{Pu}\end{array}$ & \\
\hline
\end{tabular}

(a) Thermoluminescent dosimeters.

(b) Analysis for heavy metals is dependent on their use in laboratory research projects. Only $\mathrm{Cu}$ analysis has been done to date. 
TABLE 2. Concentrations of Radionuclides in Drinking-Water Samples from Sequim (Grab Samples)

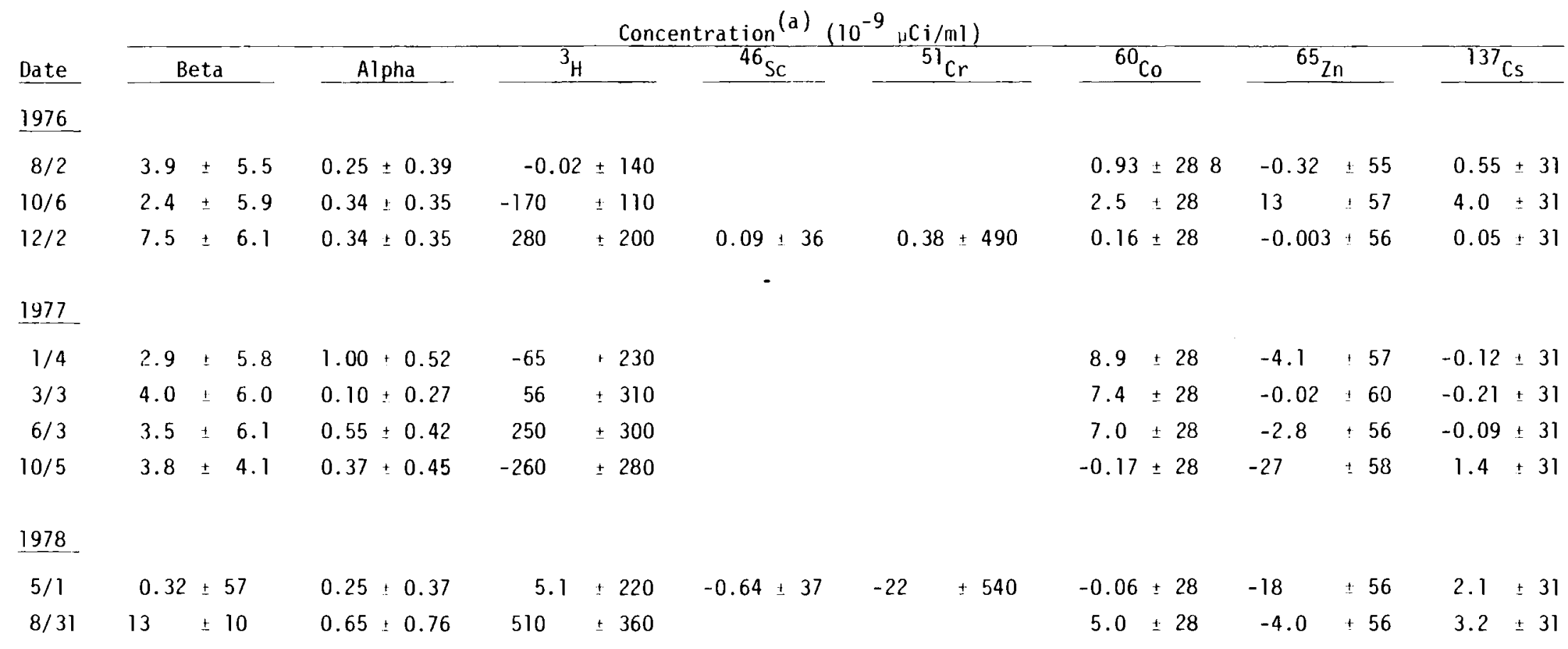

(a) Analytical results \pm 2 -sigma counting uncertainty. Negative results do not reflect a physical reality but result from the statistical uncertainty of discriminating between the sample and instrument background count rate. 
TABLE 4. Concentrations of Radionuclides in Bay water Samples from Sequim (Grab Samples)

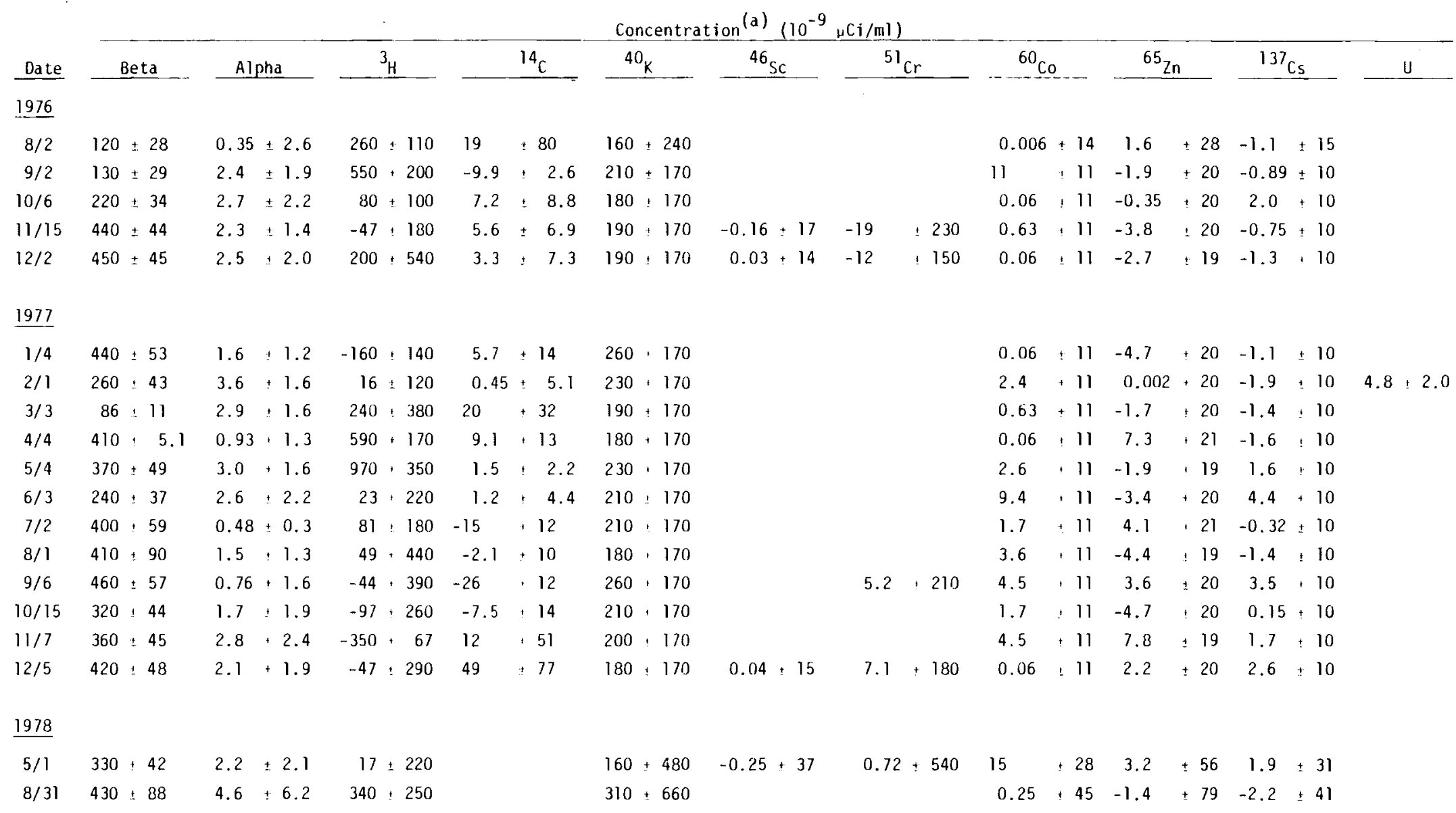

(a) Analytical results \pm 2 sigma counting uncertainty. Negative results do not reflect a physical reality but result from the statistical uncertainty of discriminating between the sample and instrument background count rate. 
TABLE 3. Total Coliform Analyses of Sequim MRL Drinking Water

\begin{tabular}{lc} 
Date & \multicolumn{2}{c}{$\begin{array}{c}\text { Total Coliform Concentration } \\
\text { (organisms per 100 ml of water) }\end{array}$} \\
$\frac{1976}{8 / 2}$ & \\
$10 / 6$ & $<2.0$ \\
1977 & $<2.0$ \\
$10 / 5$ & \\
1978 (a) & $<2.0$ \\
1st Qtr & \\
2nd Qtr & $<2.0$ \\
3rd Qtr & $<2.0$ \\
4th Qtr & $<2.0$
\end{tabular}

(a) Performed by the 01ympic Health District 
TABLE 5. Concentrations of $0 i 1$ and Copper in Bay Water Samples from Sequim (Grab Samples)

\begin{tabular}{|c|c|c|c|c|}
\hline \multirow[b]{2}{*}{ Date } & \multicolumn{2}{|c|}{ Bay Water } & \multicolumn{2}{|c|}{$\begin{array}{l}\text { Incoming Lab } \\
\text { Bay Water }\end{array}$} \\
\hline & $\begin{array}{c}0 \mathrm{il} \& \text { Grease } \\
(\mathrm{mg} / 1)\end{array}$ & $\begin{array}{l}\text { Copper } \\
(\mu \mathrm{g} / 1)\end{array}$ & $\begin{array}{c}0 \mathrm{il} \text { \& Grease } \\
(\mathrm{mg} / \mathrm{l})\end{array}$ & $\begin{array}{l}\text { Copper } \\
(\mu \mathrm{g} / \mathrm{I})\end{array}$ \\
\hline \multicolumn{5}{|l|}{1976} \\
\hline $8 / 2$ & 4.3 & 2.0 & - & - \\
\hline $10 / 6$ & 1.4 & 2.0 & 1.8 & 2.0 \\
\hline \multicolumn{5}{|l|}{1977} \\
\hline $8 / 1$ & $<1.0$ & 3.0 & - & - \\
\hline $1978^{(a)}$ & - & - & - & - \\
\hline
\end{tabular}




\section{TABLE 6. Concentrations of Radionuclides in Clams Collected at Sequim}

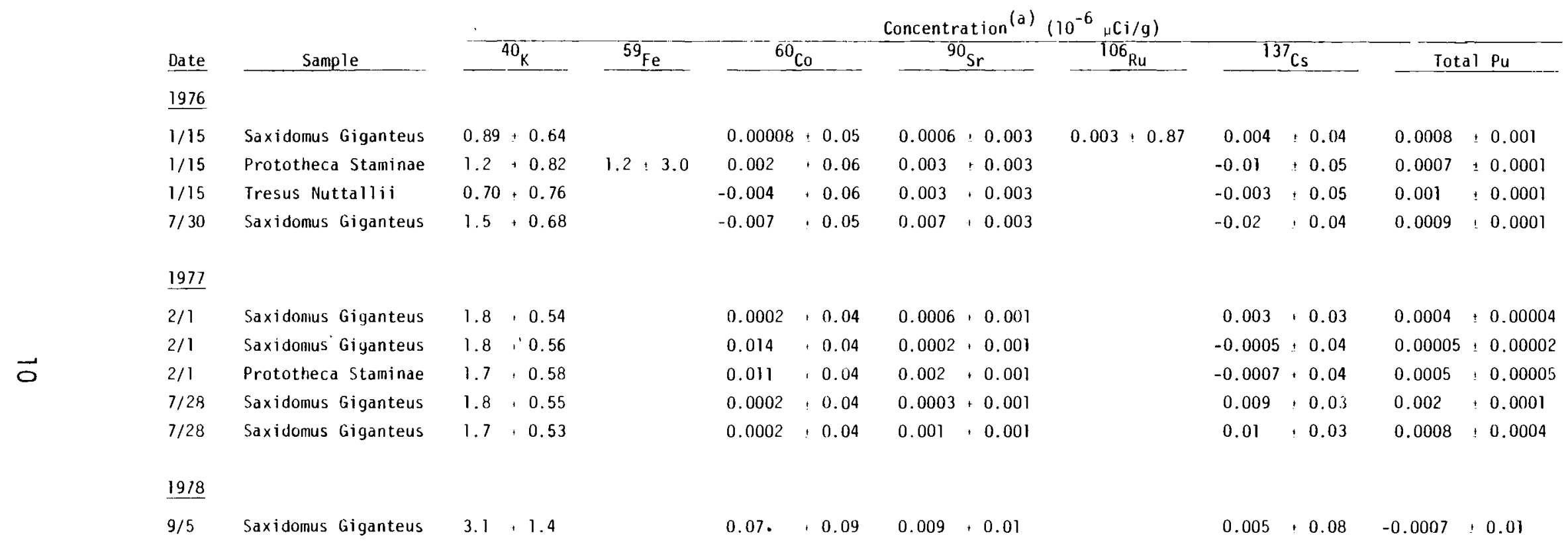

7a) Analytical results : 2 -sigma counting uncertainty. Negative results do not reflect a physical reality but result from the statistical uncertainty of discriminating between the sample and instrument background count rate. 
TABLE 7. Concentrations of Radionuclides in Kelp and Eelgrass Samples from Sequim

\begin{tabular}{|c|c|c|c|c|c|c|c|c|c|c|c|c|}
\hline \multirow{2}{*}{$\begin{array}{l}\text { Date } \\
1976\end{array}$} & \multirow[b]{2}{*}{ Sample } & \multicolumn{11}{|c|}{ Concentration ${ }^{(\mathrm{a})}\left(10^{-6}{ }_{\mu \mathrm{Ci} / \mathrm{g})}\right.$} \\
\hline & & \multicolumn{2}{|c|}{${ }^{4} 0_{K}$} & \multicolumn{2}{|c|}{${ }^{60} \mathrm{Co}$} & ${ }^{65} \mathrm{Zn}$ & \multicolumn{2}{|c|}{${ }^{90} \mathrm{Sr}$} & \multicolumn{2}{|c|}{${ }^{137} \mathrm{Cs}$} & \multicolumn{2}{|c|}{ Total Pu } \\
\hline $1 / 19$ & Kelp & 66 & \pm 2.4 & 0.0009 & \pm 0.16 & $0.31 \pm 0.47$ & 0.005 & \pm 0.004 & 0.09 & \pm 0.14 & 0.01 & \pm 0.006 \\
\hline $7 / 30$ & Kelp & 73 & \pm 2.3 & 0.020 & \pm 0.14 & $0.27+0.25$ & 0.002 & \pm 0.004 & 0.08 & \pm 0.13 & 0.006 & \pm 0.004 \\
\hline $7 / 30$ & Eelgrass & 9.8 & \pm 3.8 & 0.001 & \pm 0.26 & & 0.002 & \pm 0.008 & -0.07 & \pm 0.23 & 0.06 & \pm 0.02 \\
\hline \multicolumn{13}{|l|}{1977} \\
\hline $5 / 4$ & Kelp & 68 & \pm 2.1 & 0.08 & \pm 0.13 & $0.04 \pm 0.23$ & 0.01 & \pm 0.01 & 0.06 & \pm 0.12 & 0.002 & \pm 0.0003 \\
\hline $5 / 4$ & Eelgrass & 22 & \pm 2.9 & 0.001 & \pm 0.19 & $0.13 \pm 0.34$ & 0.02 & \pm 0.01 & 0.15 & \pm 0.18 & 0.002 & \pm 0.0003 \\
\hline $7 / 28$ & Eelgrass & 25 & \pm 5.9 & -0.04 & \pm 0.16 & $-0.20 \pm 0.30$ & 0.01 & \pm 0.004 & 0.07 & \pm 0.17 & 0.004 & \pm 0.0004 \\
\hline $7 / 28$ & Eelgrass & 17 & \pm 4.1 & 0.02 & \pm 0.13 & $-0.09 \pm 0.24$ & 0.05 & \pm 0.005 & 0.10 & \pm 0.13 & 0.002 & \pm 0.0003 \\
\hline $7 / 28$ & Kelp & 77 & \pm 9.2 & -0.19 & +0.16 & $-0.03 \pm 0.30$ & 0.05 & \pm 0.005 & -0.12 & \pm 0.15 & 0.003 & \pm 0.0004 \\
\hline $7 / 28$ & Kelp & 50 & \pm 6.1 & 0.12 & 0.14 & $0.02+0.23$ & 0.05 & +0.005 & -0.03 & \pm 0.10 & 0.001 & \pm 0.0001 \\
\hline \multicolumn{13}{|l|}{1978} \\
\hline $1 / 31$ & Eelgrass & 14 & +3.9 & 0.01 & +0.27 & $0.17 \pm 0.50$ & 0.004 & \pm 0.008 & 0.12 & +0.24 & 0.003 & \pm 0.0002 \\
\hline $6 / 5$ & Eelgrass & 4.7 & \pm 2.6 & 0.02 & +0.17 & $0.05+0.30$ & 0.06 & \pm 0.03 & -0.04 & \pm 0.16 & 0.0004 & \pm 0.0006 \\
\hline $6 / 5$ & Kelp & 5.5 & \pm 1.9 & 0.02 & \pm 0.13 & $-0.04 \pm 0.22$ & 0.03 & \pm 0.03 & -0.005 & \pm 0.12 & result & lost in lab \\
\hline $9 / 5$ & Eelgrass & 14 & \pm 6.3 & 0.11 & +0.43 & $0.09+0.77$ & 0.001 & \pm 0.01 & 0.02 & \pm 0.39 & 0.01 & \pm 0.003 \\
\hline $9 / 5$ & Kelp & 67 & \pm 6.2 & 0.002 & \pm 0.41 & $-0.06 \pm 0.73$ & 0.08 & \pm 0.01 & 0.04 & \pm 0.37 & 0.02 & +0.009 \\
\hline
\end{tabular}

(a) Analytical results \pm 2 -sigma counting uncertainty. Negative results do not reflect a physical reality but result from the statistical uncertainty of discriminating between the sample and instrument background count rate. 


\section{TABLE 8. Concentrations of Radionuclides in Sequim Soil Samples}

\begin{tabular}{|c|c|c|c|c|c|c|c|c|c|c|}
\hline \multirow[b]{2}{*}{ Sanple Location } & \multicolumn{3}{|c|}{ Naturally Occurring Radionuclides } & \multicolumn{7}{|c|}{ Artificially Produced Radionuclides } \\
\hline & ${ }^{40} \mathrm{~K}$ & ${ }^{224} \mathrm{Ra}$ & $226_{\mathrm{Ra}}$ & ${ }^{54} \mathrm{M}$ & & ${ }^{58} \mathrm{Co}$ & & ${ }^{60} \mathrm{Co}$ & & ${ }^{0} \mathrm{Sr}$ \\
\hline \multicolumn{11}{|l|}{1976} \\
\hline Near Well & $7.4+1.1$ & $0.36: 0.06$ & $0.26 \div 0.07$ & -0.008 & +0.02 & 0.0009 & +0.02 & $0.006 \pm 0.02$ & 0.01 & \pm 0.004 \\
\hline Near Storage Basin & $7.9 \pm 1.1$ & $0.33 \pm 0.06$ & $0.30: 0.08$ & -0.007 & +0.02 & 0.005 & 10.02 & $0.001+0.02$ & 0.004 & \pm 0.004 \\
\hline \multicolumn{11}{|l|}{1977} \\
\hline Near Storage Basin & $5.6 \pm 0.98$ & $0.20 \pm 0.06$ & $0.23 \div 0.07$ & 0.04 & +0.03 & -0.01 & +0.02 & $0.004+0.02$ & 0.05 & +0.02 \\
\hline Near Well & $8.7 \div 1.2$ & $0.34 \cdot 0.06$ & $0.24: 0.07$ & 0.008 & 0.03 & 0.02 & \pm 0.03 & $-0.02 \div 0.03$ & 0.01 & $\div 0.01$ \\
\hline \multicolumn{11}{|l|}{1978} \\
\hline Near Storage Basin & $8.5 \div 1.7$ & $0.41+0.06$ & $0.29: 0.07$ & 0.02 & +0.03 & 0.01 & +0.02 & $-0.004 \cdot 0.02$ & 0.03 & \pm 0.02 \\
\hline Near Well & $7.8+1.0$ & $0.37 \div 0.06$ & $0.37 \div 0.08$ & 0.009 & +0.03 & 0.02 & .0 .02 & $-0.009,0.02$ & 0.08 & \pm 0.03 \\
\hline
\end{tabular}

Artificially Produced Radionuclides

\begin{tabular}{|c|c|c|c|c|c|c|c|c|c|c|c|}
\hline $\begin{array}{l}\text { Sample Location } \\
1976\end{array}$ & \multicolumn{2}{|c|}{${ }^{95} \mathrm{ZrND}$} & $106 \mathrm{Ru}$ & $134 \mathrm{Cs}$ & ${ }^{137} \mathrm{Cs}_{\mathrm{s}}$ & ${ }^{144} \mathrm{Ce}$ & 154 EU & \multicolumn{2}{|c|}{${ }^{238} \mathrm{Pu}$} & \multicolumn{2}{|c|}{$239-240_{\mathrm{Pu}}$} \\
\hline Near well & 0.008 & +0.03 & $-0.04 \div 0.15$ & $-0.02+0.02$ & $0.07+0.03$ & & & 0.0003 & $\div 0.003$ & 0.002 & 0.001 \\
\hline Near Storage Basin & 0.04 & $\cdot 0.03$ & $-0.05 \div 0.15$ & $0.01 \div 0.02$ & $0.04: 0.03$ & & $0.004 \pm 0.17$ & 0.0007 & \pm 0.003 & 0.0004 & \pm 0.001 \\
\hline \multicolumn{12}{|l|}{1977} \\
\hline Near Storage Basin & 0.05 & $: 0.05$ & $0.01 \cdot 0.16$ & & $0.32 \pm 0.05$ & & & 0.05 & \pm 0.02 & 0.07 & \pm 0.03 \\
\hline Near Well & 0.0007 & \pm 0.03 & $-0.03,0.16$ & & $0.32: 0.03$ & & & 0.008 & \pm 0.003 & 0.003 & \pm 0.002 \\
\hline \multicolumn{12}{|l|}{1978} \\
\hline Near Storage Basin & 0.008 & +0.03 & $-0.02 \div 0.14$ & $0.02 \div 0.03$ & $0.03 \cdot 0.03$ & $0.26+0.12$ & & -0.001 & \pm 0.004 & 0.001 & +0.004 \\
\hline Near Well & 0.006 & \pm 0.03 & $-0.15+0.14$ & $-0.01 \div 0.02$ & $0.08+0.03$ & $0.11+0.11$ & & 0.002 & \pm 0.005 & 0.006 & \pm 0.006 \\
\hline
\end{tabular}
(a) Analytical results 2 sigma counting uncertainty. Negative results do not reflect a physical reality but result from the statistical
uncertainty of discriminating between the sample and instrument background count rate. 


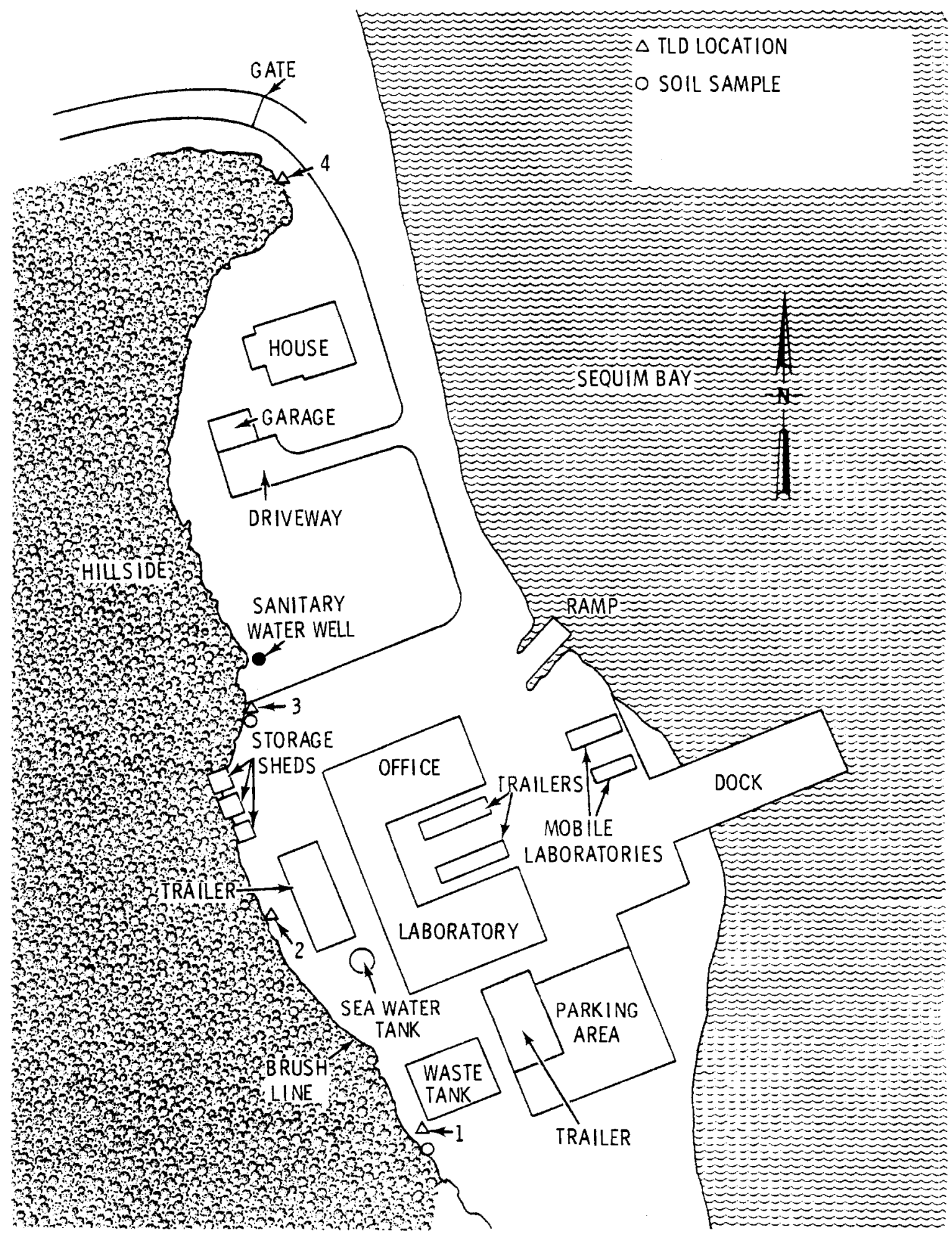

FIGURE 1. TLD and Soil Sample Locations at MRL 
TABLE 9. External Radiation Dose Rates at MRL

Dose Rate (mR/day)

$\begin{array}{r}\begin{array}{r}\text { Exposure } \\ \text { Periods }\end{array} \\ \hline\end{array}$

\begin{tabular}{cccc}
\hline $\begin{array}{c}\text { Near Tile } \\
\text { Field }\end{array}$ & Near Back & Near & N. End Near \\
(Location 1) & (Locatior & Well & $\begin{array}{c}\text { Transformer } \\
\text { (Location 2) }\end{array}$ \\
\hline
\end{tabular}

$\frac{1976}{8 / 2-9 / 16}$
$9 / 2-10 / 7$
$9 / 29-12 / 6$
$11 / 4-12 / 6$
$11 / 29-1 / 18$

0.12
0.11
0.11
0.12
0.11

0.12

0.12

0.11

0.11

0.12

0.11

0.11

0.11

0.11

0.11

0.12

0.12

0.10

0.11

0.11

$\frac{1977}{12 / 28-2 / 8}$

0.15

0.14

0.15

0.13

$1 / 28-3 / 4$

0.13

0.13

0.13

0.13

$2 / 28-4 / 8$

0.13

0.12

0.12

0.13

$3 / 30-5 / 5$

0.14

0.13

0.13

0.14

$4 / 28-6 / 6$

0.12

0.12

0.12

0.12

$5 / 30-7 / 27$

0.10

0.10

0.09

0.10

$6 / 28-8 / 2$

0.15

0.13

0.14

0.14

$7 / 27-9 / 13$

0.11

0.11

0.11

0.11

$8 / 29-10 / 14$

0.12

0.12

0.12

0.12

$9 / 28-11 / 10$

0.13

0.12

0.13

0.12

$10 / 27-12 / 7$

0.12

0.12

0.13

0.12

$11 / 28-1 / 17$

0.12

0.12

0.12

0.11

$\frac{1978}{12 / 29-2 / 7}$

0.12

0.12

0.11

0.12

$1 / 26-3 / 3$

0.12

0.11

0.12

0.12

$2 / 27-4 / 3$

0.13

0.12

0.13

0.13

$3 / 27-5 / 5$

0.13

0.11

0.13

0.11

$4 / 27-6 / 7$

0.12

0.12

0.12

0.12

$5 / 30-7 / 7$

0.14

0.13

0.14

0.14

$6 / 26-8 / 4$

0.13

0.12

0.12

0.13

$7 / 27-9 / 11$.

0.12

0.12

0.12

0.12

$8 / 28-10 / 9$

0.11

0.11

0.12

0.12

$9 / 27-11 / 16$

0.12

0.10

0.12

0.11

$10 / 30-12 / 5$

0.12

0.14

0.12

0.13

$11 / 30-1 / 5$

0.13

0.12

0.12

0.13 


\section{REFERENCES}

1. J. J. Fix and P. J. Blumer, Sequim Marine Research Laboratory Routine Environmenta 1 Measurements During CY-1976. BNWL-2267, Pacific Northwest Laboratory, Richland, WA 99352, May 1977.

2. J. J. Fix and P. J. Blumer, Sequim Marine Research Laboratory Routine Environmental Measurements During CY-1977. PNL-2569, Pacific Northwest Laboratory, Richland, WA 99352, June 1978.

3. National Council on Radiation Protection, Natural Background Radiation in the United States. NCRP Report No. 45, National Council on Radiation Protection, Washington, DC, 1975.

4. J. J. Fix and M. L. Miller, The Hanford Environmental $\mathrm{CaF}_{2}:$ Mn Thermoluminescent Dosimeter. PNL-2489, Pacific Northwest Laboratory, Richland, WA 99352 , March 1978.

5. M. C. Rand, Editor, Standard Methods for the Examination of Water and Wastewater, 14th Edition, American Public Health Association, New York, $\overline{\text { N.Y., }}$ 1976 

APPENDIX

ANALYTICAL PROCEDURES 


\section{APPENDIX}

\section{ANALYTICAL PROCEDURES}

The environmental samples collected were analyzed for radionuclides by United State Testing Company of Richland, Washington and for coliforms, oil and grease, and copper by Hanford Environmental Health Foundation of Richland, Washington. The radiological data shown in Tables 2, 4, 6, 7, and 8 include the counting result plus or minus the 2-sigma counting uncertainty. Whenever the counting result is less than the uncertainty, the counting result is considered to be less than the detection limit (2-sigma uncertainty) of the analysis. Because of the statistical nature of radionuclide counting, an occasional counting result may be slightly greater than the 2-sigma uncertainty even if the radionuclide is not present. For this reason, several environmental samples must be analyzed to provide a reliable estimate of the radionuclides present. A brief description of the analytical procedures used follows.

\section{RADIOLOGICAL ANALYSES}

Water Samples

\section{Gross Beta}

Gross beta activity is measured by a direct count of the dried residue with a gas-flow proportional counter. The counter is calibrated with a ${ }^{90} \mathrm{Sr}-\mathrm{Y}$ equilibrium source.

\section{Gross Alpha}

Gross alpha activity is measured by a low-level alpha counter following extraction of the activity into ether from a strong nitric acid. The ether phase is evaporated off and the residue plated on a stainless steel planchet. The planchet is counted with the gas-flow proportional counter, which is calibrated with a $239 \mathrm{pu}$ source. 
Gamma-Emitting Radionuclides

Gamma-emitting radionuclides are determined by the direct count of $500 \mathrm{ml}$ of sample in the well of a 9-inch $\times$ 9-inch $\mathrm{NaI}(T L)$ well detector using a multichannel gamma-ray spectrometer.

\section{Strontium-90}

Strontium-90 in water samples is precipitated with fuming nitric acid, scavenged with barium chromate, precipitated as a carbonate, transferred to a stainless steel planchet, and beta counted with a low-level beta proportional counter. After a 125-day period, the yttrium-90 daughter is separated. and counted with a low-level beta proportional counter.

\section{Tritium}

Tritium is measured in distilled water samples using a liquid scintillation spectrometer.

Clams; Eelgrass and Kelp Samples

Gamma-Emitting Radionuclides

Gamma-emitting radionuclides are determined by a direct count of the sample in the well of a 9-inch $\times$ 9-inch $\mathrm{NaI}(T L)$ well detector using a multichannel gamma-ray spectrometer.

\section{Plutonium}

After the sample is ashed in a furnace and wet ashed with concentrated nitric acid, plutonium is extracted from the sample using cation exchange resin and thenoyl trifluoroacetone. Plutonium in the eluate is electrodeposited on a stainless steel disk, exposed to nuclear track film, and then counted.

\section{Soil Samples}

Gamma-Emitting Radionuclides

Approximately 500 grams of sample are placed into a marinelli beaker and counted on a lithium-drifted germanium detector using a multichannel pulse height analyzer. 


\section{Plutonium and Strontium-90}

Soil is dried, mixed thoroughly, leached with a mixture of nitric acid and hydrochloric acids, and then passed through an ion exchange resin in $8 \mathrm{~N}$ nitric acid. The $8 \mathrm{~N}$ nitric acid retains strontium and other metal ions. This phase is precipitated with fuming nitric acid, scavenged with barium chromate, precipitated as a carbonate, and transferred to a stainless steel planchet. The sample is counted using a low-background beta proportional counter.

The plutonium is eluted from the resin column with $0.4 \mathrm{~N} \mathrm{HNO}_{3}-0.01 \mathrm{~N}$ $\mathrm{HF}$ and electrodeposited on a stainless steel disk for alpha spectrometric analyses.

NON-RADIOLOGICAL ANALYSES

\section{Coliforms}

Standard total coliform MPN technique as described in Standard Methods, 14th edition, p. 916 is used to determine coliform counts. $(5)$

Copper

Copper analysis is performed using the atomic absorption spectrophotometric technique, following concentration and extraction using ammonium pyrrolidine dithiocarbamate (APDC) and methyl isobutyl ketone (MIBK), as given in Standard Methods, 14 th ed. pp. 148-152. (5)

\section{0 il and Grease}

The partition-gravimetric method as given in Standard Methods, 14th edition, p. 515, is used to analyze for $0 i 1$ and grease. (5) 

No. of

Copies

OFFSITE

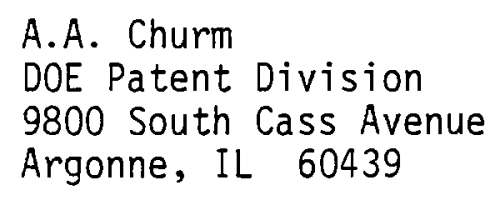

27 DOE Technical Information Center

S.I. Reed

Washington State Department of Social and Health Services

P.0. Box 1-88, MS 56-1

Olympia, WA 98504

ONSITE

2 DOE Richland Operations Office Environmental Affairs

H.E. Ransom

M.W. Tiernan

52 Pacific Northwest Laboratory

J.L. Baer

W.J. Bair

P.J. Blumer

P.E. Bramson (2)

C.I. Gibson (25)

J.R. Houston (10)

H.V. Larson

B.D. Robertson

B.E. Vaughan (3)

Technical Information (5)

Publishing Coordination (2) 


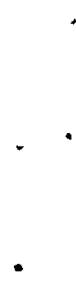

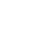

